\title{
How South African societal and circumstantial influences affect the ethical standards of prospective South African Chartered Accountants
}

\section{Author:}

Dana Nathan ${ }^{1}$

\section{Affiliation:}

${ }^{1}$ University of the Witwatersrand, School of Accountancy, Auditing Division - Senior Lecturer and Course Co-ordinator

\section{Correspondence to:}

Dana Nathan

DOI:

10.15249/9-1-79

\section{Keywords:}

ethical standards; prospective South African Chartered Accountants (CA SA's); societal influences; ethics education; students

\section{Abstract}

To address ethical consciousness through formalised tertiary education effectively, ethical standards need to be further understood. This paper investigates the effects of South African societal influences on prospective South African Chartered Accountants, through exploratory questionnaire research. Findings indicate that although participants perceive low levels of ethical behaviour in South Africa, their ethical decision making is generally not negatively influenced, most feeling the need to behave more ethically as a result. Influences from the country's environment, including lack of consequences, self-interest and justification do negatively affect some participants' ethical standards and although not statistically significant, these are considered qualitatively relevant findings. Many participants appear to believe that it is not possible to be completely ethical in business and that by remaining ethical in South African business they will be at a disadvantage. Females' ethical standards were found to have been less affected by societal influences than that of their male counterparts.

\section{Introduction}

\section{Ethics in the South African accountancy profession}

Section 100.1 of the South African Institute of Chartered Accountants (SAICA) Code of Professional Conduct, recognises that "A distinguishing mark of the accountancy profession is its acceptance of the responsibility to act in the public interest" (SAICA, 2015). Skills and expertise that accounting professionals 
carry can be seen as a form of power, and power has to be governed by the highest degree of ethical standards to avoid it leading to exploitation and abuse (Nienaber, 2010; Rossouw et al., 2011). Ethics competence is the core of the profession, with integrity and high levels of moral behaviour imperative to its credibility and functioning (Robinson et al., 2007).

Based on the premise that ethics skills can be enhanced through teaching (Verschoor, 2004; Loeb, 2007; Mitchem, 2009; Langlois \& Lapointe, 2010), the accountancy profession in South Africa, led by its professional body SAICA, took a decision as of 2007 to introduce formalised ethics education, in addition to the study of the profession's codes of ethics, as a mandatory curriculum requirement (SAICA, 2011a). Upon introduction of the 2010 "SAICA Competency Framework" (a framework relating to expectations of a South African Chartered Accountant at entry point to the profession, to uniquely equip them to better meet the needs of the market), South African universities had to commit to developing structures to ensure a strong grounding in ethics for aspirant members of the profession (SAICA, 2010; SAICA, 2011a). However, in order for these teachings to be entirely constructive, it is fundamental to fully understand ethical standards, and structure and amend ethics courses accordingly.

\section{Societal ethical challenges in South Africa}

According to Ghaffari, Kyriacou and Brennan (2008), whether students can actually apply what they learnt from ethics education to specific practical business situations depends on prevailing cultural norms. Concern from a South African perspective is that, as expressed by Rossouw (1997), we live in a challenging society where in many instances value systems are weak and moral reasoning is extremely poor. Over the past decades, the need for stronger business ethics in South Africa has been frequently expressed, with corrupt, dishonest behaviour, especially among those in positions of authority, having become all too familiar phenomena. Rossouw (1997: 1) refers to the words of the late Nelson Mandela: "We are conscious of the reality that corruption in many forms has deeply infected the fibre of our society" (Mandela, 1995). Former South African Deputy President, Kgalema Motlanthe, stated that corruption was "cancerous" and "the pestilence of corruption menacing the soul of our democracy is a life-and-death matter on which our future depends". He further stated that "what we need is a conscious intervention at the level of education to enable our nation to appreciate the devastation corruption is causing in the long term" (Motlanthe, 2011). Formal recognition in regard to this unfortunate environment resulted in South Africa being ranked 67th out of 175 countries in 2014 (72nd in 2013) by Transparency International, which publishes the corruption perceptions index annually, ranking countries by levels of corruption among public officials and politicians, as determined by expert assessments and opinion surveys (Transparency International, 2014).

\section{Upholding the Chartered Accountancy (CA (SA)) designation}

South Africa is a special case given that its Chartered Accountancy qualification is one of the most highly esteemed throughout the world, and yet its ethical environment is 
intensely challenging. Highly contrary to South Africa's Transparency International Rankings, the CA (SA) designation is currently recognised as one of the most reputable and highly regarded premier accounting and business designations throughout the world (SAICA, 2011b; SAICA, 2012). This has been formally recognised by the World Economic Forum in the 2013/2014 Global Competitiveness Report, ranking South Africa first among 148 countries in terms of the strength of "Auditing and Financial Reporting". This was the fourth consecutive year that the top ranking had been obtained by South Africa (World Economic Forum, 2014; IRBA, 2014). According to SAICA, "remaining a member of the first ranked CA (SA) designation in the world remains enviable" (SAICA, 2011b: 1).

\section{Research Objectives}

Given the above, this research was undertaken to enhance understanding of the ethical standards of future CA (SA)'s, specifically the extent of influence of South African societal circumstances and challenges. Previous studies investigating ethics determinants have not specifically explored the possible societal dimension. This paper endeavours to address this gap. Since students of today are the professionals of tomorrow, examining their current ethics attitudes is vital to the business world (Nejati et al., 2011). Piper et al. (1993:17) recognise that every educator's most fundamental question is "Who are our students?" and identify the necessity to gain this comprehensive insight. They further recognise that modern students do not dwell in a vacuum, but mirror quite faithfully the central features and characteristics of their time, which this study aims to explore.

\section{Research Design and Methodology}

\section{Exploratory model employed}

Although the researcher acknowledges that there are various factors that can impact ethical standards, this paper focuses primarily on the societal influence. Since the focus of the research was on perceptions, beliefs and attitudes, a degree of personal interpretation and a primarily qualitative, exploratory approach were necessary. This incorporated the use of a questionnaire covering a range of personal ethics investigations. A questionnaire was thought to be an effective means of obtaining more open and reliable responses than face to face interviews, due to the sensitive, personal nature of many responses that participants were asked to provide. For analysis of the data collected, a quantitative approach was used, with the utilisation of quantitative statistics.

\section{Participants}

Fourth (final) year students registered at a prominent, SAICA accredited, South African university where a vastly diverse student body exists, were used as representative of "Prospective South African Chartered Accountants". Those actively involved in the formalised university curricula offered to them through lectures were invited to 
complete a questionnaire, of which a sample of 161 was obtained. Final year students at the end of their degrees were explicitly selected for the study. This was for three reasons. Firstly, virtually all would have had exposure to formalised university ethics education. Secondly, it was deemed that near the end of the final year their ethical values would be more thoroughly developed. Thirdly, being very close to writing part one of SAICA's CA (SA) Qualifying Examination and thus being on the verge of entering the Chartered Accountancy profession, they would have a stronger sense of commitment to the profession.

Biographical characteristics of the respondents were ascertained in the first part of the questionnaire and are presented in Table 1.

Table 1: Sample Description of Respondents

\begin{tabular}{|c|c|}
\hline Gender & Percentage \\
\hline Male & 49 \\
\hline Female & 51 \\
\hline Total & 100 \\
\hline \multicolumn{2}{|l|}{ Religion } \\
\hline Christian & 51 \\
\hline Hindu & 11 \\
\hline Islamic & 9 \\
\hline Catholic & 8 \\
\hline Jewish & 7 \\
\hline Anglican & 1 \\
\hline Agnostic & 2 \\
\hline None & 11 \\
\hline Total & 100 \\
\hline \multicolumn{2}{|l|}{ Age } \\
\hline 20 & 0.6 \\
\hline 21 & 25 \\
\hline 22 & 48 \\
\hline 23 & 18 \\
\hline 24 & 8 \\
\hline 25 & 0.6 \\
\hline Total & 100 \\
\hline \multicolumn{2}{|c|}{ Completed } \\
\hline Yes & 96 \\
\hline \multicolumn{2}{|l|}{ University } \\
\hline No & 4 \\
\hline \multicolumn{2}{|c|}{ Ethics Education } \\
\hline Total & 100 \\
\hline
\end{tabular}

As indicated in Table 1, 51\% of the respondents are categorised as being female and $49 \%$ male. A majority of the respondents identified themselves to be Christians, followed by Hindus, Muslims and Catholics. Smaller proportions consisted of Jewish, Anglican and 
agnostic students. $11 \%$ did not identify as having a specific religion - leaving it open to interpretation as to whether these respondents do not follow a particular religion, or rather made a choice not to disclose it, in an attempt to avoid any association with sensitive responses provided in the questionnaire. Being a fairly large percentage, and considering the sensitive nature of many of the questions, it is the researcher's opinion that the majority of this non-disclosure was intentional.

The range of the respondents' ages was fairly small, being 20-25, with the majority falling into the 21-23 age category. The mean age was 22 . The vast majority, 96\%, of the questionnaire respondents have received formalised ethics education by way of a separate university course during earlier years, as a result of its introduction to the CA (SA) curricula several years ago.

\section{Research design and procedure}

The questionnaire, designed to establish the personal effects of ethics-related societal influences on their ethical decision making, used a variety of multiple-choice questions utilising a five-point Likert scale. An open-ended question was also provided to allow respondents to furnish any further thoughts and opinions. Any concerns with regard to the sensitive nature of the questionnaire were comprehensively addressed by guaranteeing anonymity. All formal university ethics clearance requirements were adhered to in conducting the study.

The objectives of the questionnaire were to attempt to identify, in respect of prospective CA (SA)'s:

- Their thoughts on South Africa's ethical environment.

- Whether they are influenced by ethics-related social circumstances within South Africa and if so, how.

○ Whether justification affects their ethical standards.

- Whether consequences (or rather a lack thereof) affect their ethical standards.

○ Whether self-interest affects their ethical standards.

- Whether the above differs in respect of their:

○ Gender

○ Religion

- Completion of ethics education

Initiative for this research was partly driven by a study conducted by Harvard Business School (along with Darden School of Business at the University of Virginia and the Amos Tuck School of Business at Dartmouth) demonstrating the utmost importance and necessity of formal and consistent interest by educators in addressing the question of who today's students are (Piper et al.,1993). However, due to defining uniqueness apparent in the ethics-related environment of current day South Africa and the lack 
of research pertaining to this area, it was necessary for a new questionnaire to be constructed. Although formulated specifically to address the environment, aspects from relevant prior studies and literature were incorporated, where applicable.

\section{Data analysis}

Data analysis included quantitative descriptive statistics, ordered logistic regression, and Chi-Square analysis. Ordered logistic regression was conducted where the dependent variable in each case was ordered (1-5) and the independent variables were categorically ordered as well. The questionnaire was designed to allow for the evaluation of whether an association exists between sets of categorical/ordinal variables, the respondents' characteristics - gender, age, religious beliefs and completion of formalised university ethics education - and ethical views provided. This was analysed using Chi-Square analysis and ordered logistic regression, the results consolidated and collective observations made. The answers to the open-ended question were analysed qualitatively to identify further issues relevant to the study.

\section{Literature Review}

\section{Theory of the effects of societal influences}

A commonly heard view of integrity is the belief that "you've either got it or you don't". However, Painter-Morland and Werhane (2008) argue that character is never fully formed, but always vulnerable to circumstances, and that people are malleable, responding in fascinating ways to their environment, peers and pressures around them. Similarly, Shaw (2008) posits that as humans we mirror the central features of culture and time, and various social pressures always affect us, however he argues against ethical relativism being the theory that what is right is determined by what a culture or society says is right, and that the moral system of the society in which the act occurs, is a key criterion for judging the ethical standard of an action.

A similar view, reiterated in psychological, philosophical and sociological literature, including the findings of analytic philosopher Harman (2000), insists on human behaviour being dependent not on character, but mainly on one's situation, i.e. in the contexts within which they function. This includes the impact of broader societal factors and individuals tacitly referring to role models in their moral judgments. Therefore a great deal of what is considered "character" is in fact due to specific social settings that reinforces conduct (Painter-Morland \& Werhane, 2008). Ahmed et al. (2003); Guffey and McCartney (2008), and Shaw (2008) claim that the personal standards that people adopt are formed in large part from the influence of others in their lives, and that ethics and moral judgement involve the application of basic guidelines of societal values and standards. These views are reiterated by Frank (2005), who recognises that psychologists specialising in social behaviour argue that behavioural variances are much more likely explained by situational details rather than by stable differences in individual traits. 
Ethical standards are thought to first be developed at home and later strongly influenced by the standards of an individual's surrounding community, with the improper or even criminal behaviour of others influencing some individuals' behaviour (O'Leary, 2009).

Painter-Morland and Werhane (2008) agree that a growing body of literature insists on the imbrication of individuals in the contexts within which they function and role models that individuals tacitly refer to in their moral judgments. They highlight however that many decision-making models currently used within the business ethics field are designed exclusively to exclude the effects of systemic influences, very often ignoring the impact of cultural and societal assumptions and underestimating the effect of power dynamics. In order to comprehend the nature and extent of this influence as suggested by the literature, findings of ethics determinant studies are further explored.

\section{Findings of societal influence on ethical standards}

Shaw (2008) recognises that social pressures may affect behaviour, concluding in his research that faced with the fear of violating group norms, about two thirds of the population will yield to the group. Similarly, Ogunyemi (2013) posits that no matter the good desires generated within business ethics teachings, individuals with an external locus of control may continue taking their cue from their environment. It has been found that the majority of the adult population, including accountants, possess conventional levels of moral reasoning, with evidence suggesting that these can be influenced by external factors, including religion, legal systems, the political system and specific regulations, rather than universal principles (Jackling et al., 2007).

Jackling et al. (2007) further posit that if ethical disposition can be distorted in a negative way by outside factors, so too should it be possible for culture, regulations and other pressures to influence the ethical thinking of individuals or even collective members of a profession in a positive way. This thought is explored in the findings of a South African study conducted by Morris et al. (1996), who questioned to what extent the ethics-related attitudes and actions of business professionals are affected by environmental turbulence. The study found that turbulent environmental conditions led professionals to report stronger values and ethical norms, but less ethical behavioural intentions. According to their conclusions, it appears that in turbulent times, individuals lay claim to strong values, but behave less ethically. Their values and norms appear to be discarded when faced with actual ethical dilemmas. Morris et al. (1996) maintain that these findings may be explained in terms of the theory of moral development (Kohlberg, 1969; Rest, 1986), as highly turbulent conditions, including a breakdown in law and order, may lead individuals' behaviour to be guided by reverting to reliance on peer group, avoidance of punishment or hedonistic exchange.

Bartels (1967) was one of the first to note the importance of the role of society in ethical decision making, identifying factors such as customs, religion, laws, respect, national identity and patriotism as influencing ethics (Vitell et al., 1993). In a study devoted to the question of whether persons are inherently different with respect to ethical reasoning, 
Bucar et al. (2003) find differences across countries with regards to their attitudes towards certain possible unethical behaviours. Their results are explained based on situational and contextual characteristics rather than innate personal differences. According to Guffey and McCartney (2008), once again, this aligns to Kohlberg's moral development model, whereby he posits that at conventional levels of moral development, people adapt to the moral standards of their peers or of society, particularly its laws.

Moore and Radloff (1996) refer to a study undertaken by Preble and Reichel (1988) attempting to measure attitudes towards ethics held by final-year South African accounting students at Rhodes University. Three samples of students were assessed over a three year period (1989-1991) and results were compared with samples of Israeli, American and Australian business students. Part of their findings note significant differences between the South African and Israeli students. Among other things, South Africans were found to place greater emphasis on the significance of personal moral values in influencing ethical decisions, and also that the law cannot safeguard ethical practice. In contrast, the Israeli sample had less belief in the significance of moral values and looked towards the power of law as a safeguard.

\section{The influence of "consequences" and "self-interest" on ethical standards}

Guffey and McCartney (2008) posit that the challenge is not for an individual to recognise that a moral issue exists, but rather acting ethically once an issue is recognised. They explain that a determinant of ethical standards has been thought to be the potential consequences of the dilemma, since evidence suggests a higher level of moral reasoning will be employed when the resultant consequences of the issue appear to be high. Findings of studies of accounting students by O'Leary (2009) conclude that very often the only motivation for students to act ethically appears to be if the risk of getting caught exists, not the actual nature of the act being committed. In a study of accounting students conducted by O'Leary and Cotter (2000) they find that once the risk of being caught was introduced to an ethical dilemma, the percentage of potential fraud participants fell significantly, in some cases by up to one third. Even without being informed of the actual penalties, students were significantly dissuaded from their initial choice of behaviour.

Jackling et al. (2007) determined that self-interest was the most significant factor contributing to ethical failures for accountants. The self-interest model, with its base in economics, has made strong inroads into other disciplines, with philosophers, psychologists and political scientists now relying increasingly on it to predict and explain human behaviour (Frank, 2005). Rossouw et al. (2011) affirm that many people who engage in unethical behaviour know beforehand that what they are about to do is wrong, but as they have a strong motivation to act, do so nevertheless. Guffey and McCartney (2008) provide an example of when a student, knowing it is unethical to copy from a fellow student's script, still does so, thus knowingly acting in an unethical manner in favour of self-interest. Elias and Farag (2010) identify that the desire for money may have a potential negative effect on accounting students' ethical behaviour especially 
with regard to illegal activities, referring to a study conducted assessing United States business and psychology students, where Tang and Chen (2008) find that the love of money predicted unethical behaviour for business students but not for psychology students.

\section{The influence of ethics education on accounting students' ethical standards}

Considerable literature has addressed the question of whether accountants and accounting students can be trained to be ethical (Salter et al., 2001). According to Langlois and Lapointe (2010), in a three-year action-research study evaluating whether ethics can be learned, findings indicated a positive impact and improved ethics awareness as a result of ethics training interventions. Supporting this finding, various studies (Armstrong, 1993; Shaub, 1994) have also concluded on positive effects in this regard (Cooper et al., 2008). However not all research supports the belief of ethical growth through education. Green and Weber (1997), Low et al. (2008) and Tang and Chen (2008) suggest that formal ethics training has little relevance on ethical development and fails to profoundly impact the ethical sensitivity of accounting students. Other empirical studies (Ponemon, 1993; Lampe, 1996) find no significant change in students' ethical reasoning and development as a result of formal ethics interventions (Cooper et al., 2008).

In summary, the literature above suggests that ethical standards can be affected by societal influences and circumstances, which includes the effects of a lack of consequences and self-interest in relation to ethical decision making. In addition, it is suggested that the completion of formalised ethics education may possibly affect ethical standards. Clearly these are areas that warrant ongoing research, specifically from the South African perspective.

\section{Empirical Findings}

Having established the biographical characteristics of the respondents, subsequent sections of the questionnaire gauged students' perceptions on a five-point Likert scale, where 1 represented strongly disagree and 5 represented strongly agree, and appropriate statistical tests were subsequently carried out. It should be strongly emphasised that although non-statistically significant deviations identified could be interpreted as meaningless, in the context of this study statistically small findings and even neutrality is often considered qualitatively meaningful, as it represents a deviation from the strong ethical values critical to South Africa's accountancy profession. 
South Africa's current ethical environment: Perceptions,

beliefs and effects thereof

Table 2: Perceptions of South Africa's Ethical Environment: Mean Scores and Statistical Illustration of Findings

\begin{tabular}{|c|c|c|c|c|c|c|}
\hline Statement & Mean & $\begin{array}{l}\text { Completely } \\
\text { disagree (1) }\end{array}$ & $\begin{array}{l}\text { Disagree } \\
\text { (2) }\end{array}$ & $\begin{array}{c}\text { Neutral } \\
\text { (3) }\end{array}$ & $\begin{array}{c}\text { Agree } \\
\text { (4) }\end{array}$ & $\begin{array}{c}\text { Completely } \\
\text { Agree (5) }\end{array}$ \\
\hline $\begin{array}{l}\text { I believe South Africa to be } \\
\text { a country with strong value } \\
\text { systems and ethical behaviour }\end{array}$ & 2.33 & $14.7 \%$ & $58.7 \%$ & $7.3 \%$ & $17.3 \%$ & $2.0 \%$ \\
\hline $\begin{array}{l}\text { My ethical decision making is } \\
\text { influenced as a result of this } \\
\text { belief (my answer to the above) }\end{array}$ & 2.66 & $15.6 \%$ & $39.5 \%$ & $12.2 \%$ & $28.6 \%$ & $4.1 \%$ \\
\hline $\begin{array}{l}\text { It makes me inclined to feel the } \\
\text { need to behave more ethically }\end{array}$ & 3.92 & $1.9 \%$ & $10.4 \%$ & $7.5 \%$ & $53.8 \%$ & $26.4 \%$ \\
\hline $\begin{array}{l}\text { It makes me inclined to feel the } \\
\text { right to behave less ethically }\end{array}$ & 2.11 & $35.9 \%$ & $34.8 \%$ & $13 . \%$ & $15.2 \%$ & $1.1 \%$ \\
\hline $\begin{array}{l}\text { I believe that ethical } \\
\text { expectations, attitude and } \\
\text { behaviour differs in South } \\
\text { Africa in comparison to other } \\
\text { jurisdictions }\end{array}$ & 3.74 & $3.4 \%$ & $13.4 \%$ & $6.0 \%$ & $59.7 \%$ & $17.4 \%$ \\
\hline $\begin{array}{l}\text { I believe that there is a lot } \\
\text { of unethical practices and } \\
\text { behaviour in the South African } \\
\text { business environment }\end{array}$ & 4.24 & $0.7 \%$ & $4.0 \%$ & $6.7 \%$ & $48.0 \%$ & $40.7 \%$ \\
\hline
\end{tabular}

Table 2 illustrates respondents' overall views of current day South Africa and the effect on their ethical disposition. A strongly negative perception of ethics in South Africa was identified, evidenced by a high mean score of 4.24 with respect to the statement, "I believe that there is a lot of unethical practices and behaviour in the South African business environment", with only a minimal $4.7 \%$ not in agreement, reflected in the findings in Table 2. Further findings indicate that ethical expectations, attitude and behaviour differ in South Africa in comparison to other jurisdictions, according to a significant $77 \%$ of respondents.

As further evidenced in Table 2, an undeniably large majority have a perception that the country's ethical standards are questionable, with a low mean score of 2.33 , and a fairly low percentage of respondents, $19 \%$, actually agreeing with the belief that South Africa is a country with "strong value systems and ethical behaviour". The above findings all highlight the negative perception of ethical conduct within South Africa.

However, even though the perception of strong ethical values in South Africa is low, the results of further investigation are fairly encouraging, in that it would appear that this negative perception has generally had a positive influence on these individuals' ethical disposition. This being evident, as illustrated in Table 2, by the indication that they either feel the "need to behave more ethically", having obtained a mean score of 3.92, or instead did not feel they had the "right to behave less ethically", with a mean score of 2.11 . In absolute terms, $80 \%$ of respondents have allowed the overall negative perception of 
South Africa's ethical culture to encourage them to feel the need to improve their own personal ethical behaviour. Similarly $71 \%$ do not believe that it gives them the right to behave less ethically.

Although the majority viewpoints on these matters were encouraging, the remainder of the respondents' beliefs have to leave one with a sense of strong concern - $16 \%$ of students felt the right to behave less ethically as a result of the low ethical perception of South Africa. Additionally, a further $13 \%$, who have chosen to remain neutral, possibly hold a similar concerning viewpoint. This potential $29 \%$ is considered to be a qualitatively significant deviation and thought-provoking finding in view of the fact that this immoral mind-set represents the views of some future South African Chartered Accountants who have very strong demands for ethical behaviour in their professional future. This finding is consistent with the literature (O'Leary, 2009; Ghaffari et al., 2008; Guffey \& McCartney, 2008; Jackling et al., 2007; Bucar et al., 2003) which identifies the effects of negative social surroundings and ethical culture influencing the ethical standards held by some individuals.

It is however encouraging that the findings of the current study indicate that the statistical majority of respondents have not allowed South Africa's situation to affect their ethical standards negatively. However the findings of Morris et al. (1996) should be borne in mind, whereby they find that in turbulent times, individuals may lay claim to strong values, but behave less ethically as values and norms appear to be discarded when faced with actual ethical dilemmas. This being in line with the theory of moral development (Kohlberg, 1969; Rest, 1986) previously discussed.

In response to "It makes me inclined to feel the right to behave less ethically" (As per Table 2)

Table 2(A): Perceptions of South Africa's Ethical Environment, by Religion

\begin{tabular}{|l|c|c|c|c|c|c|}
\hline \multirow{2}{*}{ Likert Response } & \multicolumn{6}{|c|}{ Religion } \\
\cline { 2 - 7 } & Christian & Islamic & Jewish & Catholic & Hindu & Other(*) \\
\hline 1. Strongly Disagree & $9.5 \%$ & $7.7 \%$ & $30 \%$ & $30.8 \%$ & $11.8 \%$ & $0 \%$ \\
\hline 2. Agree & $35.1 \%$ & $30.8 \%$ & $40 \%$ & $46.2 \%$ & $52.9 \%$ & $67 \%$ \\
\hline 3. Neutral & $12.2 \%$ & $23.1 \%$ & $10 \%$ & $0 \%$ & $23.5 \%$ & $33 \%$ \\
\hline 4. Disagree & $36.5 \%$ & $30.8 \%$ & $20 \%$ & $23.1 \%$ & $11.8 \%$ & $0 \%$ \\
\hline 5. Strongly Disagree & $6.8 \%$ & $7.7 \%$ & $0 \%$ & $0 \%$ & $0 \%$ & $0 \%$ \\
\hline
\end{tabular}

$\left(^{*}\right)$ "Other" comprising Anglican and agnostic respondents, represents a very small number of respondents to be considered a significant finding

To further analyse the findings per Table 2, Chi-Square analysis and Ordered logistic regression was performed in order to establish whether any associations exists between two sets of categorical/ordinal variables. As illustrated in Table 2(a), it was found that with regard to religion, $a$ highly significant $(<1 \%)$ relationship exists between the perception that South Africa is "a country with strong value systems and ethical behaviour" and the respondents' religion. In this regard, a significant number of respondents that were Jewish, Catholic and Hindu felt that their perception of South African ethical behaviour did not influence their own personal ethics. In the case of Christian and Muslim 
respondents, as many felt their perception of South African ethical behaviour influenced their own personal ethical behaviour, as those that felt it did not. It was also found that a significant relationship (5\%) exists between the need to behave more ethically in South Africa and the religion of the respondent, thus indicating that the major religious groups appeared to support the contention of the need to behave more ethically. This aligns to Conroy and Emerson (2008) who find that religiosity is significantly correlated with ethical perceptions and higher ethical attitudes. According to them, in attempting to explain why religion may affect ethical attitudes, researchers have turned to Kohlberg's (1981) stage development theory as a basis, arguing that the moral instructions and values of religious structures, helps to support morality.

Table 3: Personal Ethics Beliefs and Attitudes: Mean Scores and Statistical Illustration of Findings

\begin{tabular}{|l|r|r|r|r|r|r|}
\hline Statement & Mean & $\begin{array}{c}\text { Completely } \\
\text { disagree (1) }\end{array}$ & $\begin{array}{c}\text { Disagree } \\
\text { (2) }\end{array}$ & $\begin{array}{c}\text { Neutral } \\
\text { (3) }\end{array}$ & $\begin{array}{c}\text { Agree } \\
\text { (4) }\end{array}$ & $\begin{array}{c}\text { Completely } \\
\text { Agree (5) }\end{array}$ \\
\hline $\begin{array}{l}\text { I believe that it is } \\
\text { impossible to be } \\
\text { completely ethical in the } \\
\text { business world }\end{array}$ & 3.13 & $10.6 \%$ & $30.5 \%$ & $6.6 \%$ & $40.4 \%$ & $11.9 \%$ \\
\hline $\begin{array}{l}\text { I believe that professionals } \\
\text { in South Africa who } \\
\text { remain completely ethical } \\
\text { in business will be at a } \\
\text { disadvantage }\end{array}$ & 2.74 & $17.4 \%$ & $34.9 \%$ & $10.1 \%$ & $30.9 \%$ & \\
\hline $\begin{array}{l}\text { I believe that should I } \\
\text { commit an unethical act in } \\
\text { South Africa, in comparison } \\
\text { to most other jurisdictions, } \\
\text { there would be a much } \\
\text { greater chance of no } \\
\text { consequences }\end{array}$ & 3.23 & $7.5 \%$ & $23.1 \%$ & $17.0 \%$ & $43.5 \%$ & $6.7 \%$ \\
\hline
\end{tabular}

A startling result observed, as illustrated in Table 3, with regard to "I believe that it is impossible to be completely ethical in the business world", are findings reflecting that a large number, $52 \%$, of these "prospective CA (SA)'s" believe it is not possible to be completely ethical in business. Considering that these represent the views of prospective South African professionals about to embark into the business world, this viewpoint being held at the outset of their careers can certainly be considered to be an area of great concern.

Earlier findings with regard to the perception of differences between South Africa and other countries, that were identified in Table 2, are enhanced by the results per Table 3. Results highlight that a large proportion, over $52 \%$, believe that if they committed an unethical act in South Africa, in comparison to most other jurisdictions, there would be a much greater chance of no consequences. With a further $17 \%$ remaining neutral, and a mean of 3.23 evident, this signifies the identification of a concerning perception. An equally concerning perception identified in a further finding per Table 3, with a mean 
score of 2.74, are a substantial $37.6 \%$ of respondents who "believe that professionals in South Africa who remain completely ethical in business will be at a disadvantage". These findings are considered to be of concern in light of the findings of studies which suggest that people are usually motivated by self-interest, and those that identify the fear of being caught is one of few reasons that business professionals might avoid unethical conduct.

\section{South African societal influences: Justification, lack of consequences and self-interest}

Table 4: Societal Influences - Justification, Lack of Consequences and Self-Interest: Mean Scores and Statistical Illustration of Findings

\begin{tabular}{|c|c|c|c|c|c|c|}
\hline Statement & Mean & $\begin{array}{l}\text { Completely } \\
\text { disagree (1) }\end{array}$ & $\begin{array}{c}\text { Disagree } \\
\text { (2) }\end{array}$ & $\begin{array}{c}\text { Neutral } \\
\text { (3) }\end{array}$ & $\begin{array}{l}\text { Agree } \\
\text { (4) }\end{array}$ & $\begin{array}{c}\text { Completely } \\
\text { Agree (5) }\end{array}$ \\
\hline $\begin{array}{l}\text { Once in business, if I was certain } \\
\text { that I could get away with it should } \\
\text { I commit an unethical act, I would } \\
\text { engage in such behaviour }\end{array}$ & 1.85 & $39.2 \%$ & $43.9 \%$ & $9.5 \%$ & $7.4 \%$ & $0.0 \%$ \\
\hline $\begin{array}{l}\text { Knowing that many unethical or } \\
\text { corrupt actions committed have } \\
\text { had little or no consequences } \\
\text { for the perpetrators, I feel more } \\
\text { inclined and justified to engage in } \\
\text { unethical behaviour }\end{array}$ & 1.79 & $40.3 \%$ & $48.3 \%$ & $4.7 \%$ & $6.0 \%$ & $0.7 \%$ \\
\hline $\begin{array}{l}\text { To act unethically feels somewhat } \\
\text { justifiable, since I am aware that } \\
\text { many in high-standing business } \\
\text { positions have done so }\end{array}$ & 2.09 & $29.3 \%$ & $49.3 \%$ & $8.0 \%$ & $9.3 \%$ & $4.0 \%$ \\
\hline $\begin{array}{l}\text { To act unethically feels somewhat } \\
\text { justifiable, since I am aware } \\
\text { that many in positions of public } \\
\text { authority and power in South Africa } \\
\text { (e.g. Government) have done so }\end{array}$ & 1.89 & $43.0 \%$ & $39.6 \%$ & $4.7 \%$ & $10.8 \%$ & $2.0 \%$ \\
\hline $\begin{array}{l}\text { Knowing that many unethical or } \\
\text { corrupt actions committed have } \\
\text { resulted in high returns, such as } \\
\text { monetary rewards, status and } \\
\text { success, I feel more inclined to } \\
\text { engage in unethical behaviour }\end{array}$ & 1.88 & $40.0 \%$ & $44.7 \%$ & $4.7 \%$ & $8.7 \%$ & $2.0 \%$ \\
\hline
\end{tabular}

The concept of "justification", as a result of societal circumstances, has been identified as a determinant of some individuals' ethical reasoning, illustrating that unfortunately it is not always the immoral consideration of the dilemma that halts unethical decision making. As evidenced in Table 4, in response to the statement: "To act unethically feels somewhat justifiable, since I am aware that many in high-standing business positions have done so", over $13 \%$ responded in the affirmative. Similarly, almost $13 \%$ of students feel that it is somewhat justifiable to commit an unethical act in South Africa, since they are aware that "many in positions of public authority and power in South Africa (e.g. 
Government) have done so". Although quantitatively not a statistically large finding, due to the qualitative intensity of these young future professionals displaying such a negative mind-set, it is considered to be a finding that raises and will remain a concern. This is unfortunate evidence of South African societal factors and external influences playing a part in negatively impacting the mind-sets and ultimate justification of unethical standards held by some respondents. Once again, these findings are in line with the literature (Morris et al., 1996; Bucar et al., 2003; Jackling et al., 2007; Ghaffari et al., 2008; Guffey \& McCartney, 2008) identifying the effect of social surroundings and ethical culture acting as a determinant of ethics for some individuals.

As is evident in Table 4, the "consequences", or rather lack thereof, has also been found to be a determinant of some prospective CA (SA)s' ethical reasoning. This has been identified in response to the statements, "Once in business, if I was certain that I could get away with it should I commit an unethical act, I would engage in such behaviour" and "Knowing that many unethical or corrupt actions committed have had little or no consequences for the perpetrators, I feel more inclined and justified to engage in unethical behaviour". As reflected in Table 4, although statistically small percentages of $7.4 \%$ and $6.7 \%$ respectively have agreed to these statements, the qualitative aspect of both of these findings is concerning. In addition, neutrality has been identified for a further $9.5 \%$ and $4.7 \%$ respectively, representing a fair number of respondents refraining from taking a strong stance, thus displaying concerning unethical standards at the outset of their professional careers. These findings are in line with the literature (O'Leary \& Cotter, 2000; Guffey \& McCartney, 2007; O'Leary, 2009) citing evidence suggesting that higher levels of moral reasoning will be employed when the resultant consequences appear high and thus the consequences of an action is often the ethics determinant for some, not the actual immorality of the decision. Considering that South Africa's current environment often displays evidence of a lack of (sufficient) consequences for perpetrators of questionable actions, this area of weakness is thus an area of concern since it will act as a determinant of ethical standards for some individuals, as the current study's findings confirm.

Table 4 also highlights the effect of self-interest on ethical standards, with $11 \%$ of respondents agreeing that high returns, such as monetary rewards, status and success make them feel more inclined to engage in unethical behaviour. Self-interest acting as an ethical determinant, is in line with literature findings (Frank, 2005; Jackling et al., 2007; Elias and Farag, 2010; Guffey \& McCartney, 2008; Tang \& Chen, 2008). Once again, considering that South Africa's current environment often displays evidence of high returns, status and success for perpetrators of questionable behaviour, this is thus another area of concern as self-interest may act as an ethical determinant for some individuals, as evidenced in the current study's findings. 
Table 5: Male Vs. Female: Mean Scores

\begin{tabular}{|l|r|r|}
\hline & \multicolumn{2}{|c|}{ Average Mean score } \\
\cline { 2 - 3 } & \multicolumn{1}{|c|}{ Male } & Female \\
\hline I believe that it is impossible to be completely ethical in the business world & 3.32 & 2.93 \\
\hline $\begin{array}{l}\text { I believe that should I commit an unethical act in South Africa, in comparison } \\
\text { to most other jurisdictions, there would be a much greater chance of no } \\
\text { consequences }\end{array}$ & 2.11 & 1.66 \\
\hline $\begin{array}{l}\text { To act unethically feels somewhat justifiable, since I am aware that many in } \\
\text { high standing business positions have done so }\end{array}$ & 2.29 \\
\hline $\begin{array}{l}\text { Once in business, if I was certain that I could get away with it should I commit } \\
\text { an unethical act, I would engage in such behaviour }\end{array}$ & 2.01 \\
\hline $\begin{array}{l}\text { To act unethically feels somewhat justifiable, since I am aware that many in } \\
\text { positions of public authority and power in South Africa (e.g. Government) } \\
\text { have done so }\end{array}$ & 1.89 \\
\hline $\begin{array}{l}\text { Knowing that many unethical or corrupt actions committed have had little or } \\
\text { no consequences for the perpetrators, I feel more inclined and justified to } \\
\text { engage in unethical behaviour }\end{array}$ & 1.69 \\
\hline $\begin{array}{l}\text { Knowing that many unethical or corrupt actions committed have resulted } \\
\text { in high returns, such as monetary rewards, status and success, I feel more } \\
\text { inclined to engage in unethical behaviour }\end{array}$ & 2.0 \\
\hline
\end{tabular}

Findings were further analysed in order to identify a possible correlation to gender. Table 5 illustrates lower mean scores for female versus male respondents, indicating that females display higher levels of ethical standards than their male counterparts. This reflects that female respondents' ethical decision making is based more on actual ethical and moral reasoning, rather than by the consideration and effects of other influences, such as societal circumstances (including justification, lack of consequences and selfinterest) that often alter ethical decision making and ethical standards. This is in line with previous findings such as Bateman and Valentine (2010) who find that women place more importance on an overall moral philosophy than do men, and that women have higher intentions to behave ethically. Other research (Haswell \& Jubb, 1995; O'Leary, 2009) finds differences in ethical standards between the sexes, with male students appearing more prepared to act unethically than females.

In order to identify any possible correlation to the completion of formalised university ethics education, findings were further analysed using Chi-Square analysis and Ordered logistic regression. A significant relationship (5\%) was found to exist between whether or not respondents attended a formalised university ethics course and the belief of the right to behave less ethically in South Africa. Further analysis, as illustrated in Table 6, indicates some fairly large statistical differences and thus the appearance of a degree of association between having received formalised ethics education and respondents' ethical viewpoints. These results therefore possibly highlight the positive effect that formalised ethics education may have had on prospective CA (SA)'s, in line with previous studies (Piper et al., 1993; Verschoor, 2004; Guffey \& McCartney, 2008; Cooper et al., 
2008). However due to the minimal absolute number of respondents having not had formalised ethics education, generalisation of this finding should be done with extreme caution. Statistically this cannot be used to draw a valid and reliable conclusion. In addition it needs to be considered that those that have not completed a formal ethics course are presumably weaker students (as they presumably repeated courses and have therefore taken longer to reach their final year at university, based on the timing of the ethics course being introduced) and are perhaps a bit disillusioned by their failure, thus displaying different ethical responses.

Table 6: Ethics Education Findings: Mean Scores

\begin{tabular}{|c|c|c|}
\hline & \multicolumn{2}{|c|}{ Average Mean } \\
\hline & $\begin{array}{l}\text { Completed } \\
\text { Ethics Education }\end{array}$ & $\begin{array}{l}\text { No Ethics } \\
\text { Education }\end{array}$ \\
\hline $\begin{array}{l}\text { To act unethically feels somewhat justifiable, since I am aware } \\
\text { that many in high standing business positions have done so }\end{array}$ & 2.04 & 3.33 \\
\hline $\begin{array}{l}\text { I believe that professionals in South Africa who remain } \\
\text { completely ethical in business will be at a disadvantage }\end{array}$ & 2.71 & 3.67 \\
\hline $\begin{array}{l}\text { I believe that should I commit an unethical act in South Africa, in } \\
\text { comparison to most other jurisdictions, there would be a much } \\
\text { greater chance of no consequences }\end{array}$ & 3.20 & 4.0 \\
\hline $\begin{array}{l}\text { Once in business, if I was certain that I could get away with } \\
\text { it should I commit an unethical act, I would engage in such } \\
\text { behaviour }\end{array}$ & 1.82 & 2.50 \\
\hline $\begin{array}{l}\text { To act unethically feels somewhat justifiable, since I am aware } \\
\text { that many in positions of public authority and power (e.g. } \\
\text { Government) have done so }\end{array}$ & 1.85 & 2.83 \\
\hline $\begin{array}{l}\text { Knowing that many unethical or corrupt actions committed have } \\
\text { had little or no consequences for the perpetrators, I feel more } \\
\text { inclined and justified to engage in unethical behaviour }\end{array}$ & 1.76 & 2.33 \\
\hline $\begin{array}{l}\text { Knowing that many unethical or corrupt actions committed have } \\
\text { resulted in high returns, such as monetary rewards, status and } \\
\text { success, I feel more inclined to engage in unethical behaviour }\end{array}$ & 1.85 & 2.50 \\
\hline
\end{tabular}

\section{Other findings}

The concluding part of the questionnaire allowed for the opportunity to elaborate on any matters previously responded to and to express further personal views. These comments were analysed qualitatively to identify any further issues that emerged. Key findings identified included the following common views being expressed:

- In regard to the moulding and influencing of ethics, expression of the belief that ethics is affected by circumstances and the people that individuals surround themselves with, many believing that ethics cannot be taught.

- The opinion that formal ethics education needs to be addressed at a much earlier stage than university level, rather during schooling years, i.e. during childhood where moral grounding could still be nurtured. 
- A strong belief that the formalised university ethics education that they were exposed to, was too philosophical and not sufficiently practical for knowing what to do in situations. The thought was that the course should provide detailed guidance to take informed decisions and to better understand possible realistic ethical dilemmas that they may be exposed to once active members of the profession.

This thought aligns to Piper et al. (1993) who recognise that university ethics education needs to provide interesting and appropriately relevant examples with regard to specific societal circumstances in order to engage students. They posit the need to incorporate carefully researched case studies about outstanding leaders that students are familiar with, the challenges that these individuals faced, what decisions and actions they took, and what led them to conduct their affairs as they did.

Other interesting expressions of opinion provided by respondents included the following statements:

- "If something is wrong, it is wrong - regardless of who has done it or how many people do it."

- "Ultimately every individual views ethics differently."

- 'Definitions of 'ethical' and 'moral' differ depending on where you are and who you speak to, as such the justifiability of unethical or immoral behaviour is always up for debate. There is no clear answer."

- "In my opinion it generally is as a result of opportunity that unethical behaviour occurs."

- "The nature of people is to be unethical but the knowledge of a perfect 'right' stops us from doing what we shouldn't."

- "My ethical decisions would be greatly affected by circumstance."

- "The unethical practices of the South African government give me the urgency to change the way business is done and rise above their unacceptable behaviour."

- "The lack of punishment in our country is what allows people to think it is ok."

- It's unfair to think that South Africa is more accepting of such behaviour, but the consequences are less stringent.”

- "Since it is a fact that not everyone has the same ethical beliefs, we are unable to work together towards a common goal of a non-corrupt South Africa."

\section{Conclusion}

If the South African Chartered Accountancy profession is going to be in a position to maintain its professional status and integrity, ethical standards need to be maintained and improved through constructive education and training. However as recognised by Guffey and McCartney (2008), until the moral decision-making rationale among prospective accountants is truly understood, it is doubtful that effective strategies will be able to 
be developed to enhance these belief systems through education. This area of research was therefore considered necessary, to explore the effect of South African societal and circumstantial influences on prospective CA (SA)'s. This objective having been achieved through the use of an anonymous questionnaire, requiring personal responses in regard to ethical beliefs, attitude and standards.

Evidence of this research indicated a perceived low level of ethical behaviour in South Africa, although a large majority of respondents felt that they were not negatively influenced by this, and rather felt the need to behave more ethically as a result. Of concern was the finding that a large portion of these prospective CA (SA)'s maintain the belief that it is not possible to be completely ethical in the business world, with many further believing that by remaining ethical in South African business, they will actually be at a disadvantage. Various South African societal influences, including the concept of justification, lack of consequences and self-interest, all evident within the country's environment, were found to have affected some prospective CA (SA)s' ethical standards. Although not statistically significant, these findings were considered to be qualitatively important due to both the unethical nature of the responses as well as the nature of the respondents, being prospective professionals at the brink of their careers. Additional findings also noted that females tend to display higher levels of ethical standards than their male counterparts, having not been as affected by South African societal influences.

The findings of this research allow educational policy makers to gain insight and perspective into the minds of those for whom ethics courses are aimed to educate. The results could thus aid in assisting South African universities, if necessary, in revisiting and modifying the instructional approach that is currently being adopted, by applying the findings to the design, content creation and educational structure of ethics curriculum. In a country and within a profession where decision making based on one's strong personal integrity and own ethical judgement is fundamental, ethics education needs to attempt to raise ethical consciousness, allowing future professionals to resist pressures and motivations commonly evident within South Africa. Thus incorporating aspects of South African societal influences, dealing with the concepts of justification, lack of consequences and possible negative business or political "role-models" within the country, as well as addressing the belief that remaining ethical in South African business will be a disadvantage, may need to be integrated into formalised ethics teachings to prospective CA (SA)'s.

\section{Limitations of Research}

This study is not without limitations. Firstly, in terms of the responses, whether they are true reflections of what the participants would actually do in a practical real-life situations is a factor which will remain unknown. This is a limitation applicable to most studies of this kind (O'Leary, 2009). Secondly, due to the sample used to conduct the analysis, being drawn from only one specific location, the validity of the findings may be uncertain for the purpose of making inference about the perspectives of the general 
population. However on an exploratory level the findings remain insightful and rather than be used as independent conclusive evidence, should be utilised in conjunction with the theory provided by the literature. Lastly, as previously mentioned, to the best of the researcher's knowledge, limited current research has been carried out in South Africa with regard to the area of study that this paper endeavoured to address. This factor, together with the uniqueness of South Africa's current societal environment, prohibits meaningful comparisons being made with other studies, both locally and internationally.

\section{Future research}

Given the restriction on the generalisability of the findings of this research imposed by the sample being students at only one South African university, it may be beneficial for this study to be extended to various universities throughout the country. This is in order for the validity of the findings to be more certain about the perspectives of the general population, and to identify possible differences in the effects of variations of ethics education. Furthermore, future research could be carried out with regard to obtaining the perceptions of fully qualified CA (SA)'s who are already active members of the accountancy profession and comparing the results to the findings of this research, in order to identify any possibly interesting comparisons.

As observed by Vitell et al. (1993) and Salter et al. (2001), in studies conducted investigating constructs affecting an individual's perceptions in ethics-related situations, few have been cross-cultural in content, in spite of the importance of this factor. Ideally, several countries need to be included in a study so that the effects of cultural dimensions can be reliably measured. Although this may prove challenging and several studies will possibly be needed, this is considered a very worthwhile research endeavour in the area of how societal circumstances and culture determine ethical perceptions.

Finally, in order to evaluate the effects of the introduction of formalised university ethics education into the $\mathrm{CA}(\mathrm{SA})$ training programme, as a result of SAICA requirements, viable research could involve analysing South African universities' and SAICA reports of ethicsrelated violations among its students and members (specifically trainee accountants) respectively, as well as incidences of cheating among those writing CA (SA) Qualifying Examinations. Comparisons could be made with results prior to the introduction of formalised ethics education, in order to evaluate its viability and the benefits that it has provided.

\section{References}

Ahmed, M.M., Chung, K.Y. \& Eichenseher, J.W. 2003. Business Students' Perception of Ethics and Moral Judgment: A Cross-Cultural Study. Journal of Business Ethics, 43(89): 89-102.

Armstrong, M.B. 1993. Ethics and Professionalism in accounting education: A sample Course. Journal of Accounting Education, 11: 77-92.

Bartels, R. 1967. A Model for Ethics in Marketing. Journal of Marketing, 1: 20-26.

Bateman, C.R. \& Valentine, S.R. 2010. Investigating the effects of gender on consumers' moral philosophies 
and ethical intentions. Journal of Business Ethics, 95(3): 393-414.

Bucar, B., Glas, M. \& Hisrich, R.D. 2003. Ethics and entrepreneurs: An international comparative. Journal of Business Venturing, 18 (2): 261-281.

Conroy, S.J \& Emerson, T.L.N. 2004. Business Ethics and Religion: Religiosity as a predictor of ethical awareness among students. Journal of Business Ethics, 50(4): 383-396.

Cooper, B.J., Leung, P., Dellaportas, S., Jackling, B. \& Wong, G. 2008. Ethics Education for Accounting Students - a Toolkit Approach. Accounting Education: an international journal, 17(4): 405-430.

Elias, R.Z. \& Farag, M. 2010. The relationship between accounting students' love of money and their ethical perception. Managerial Auditing Journal, 25(3): 269-281.

Frank, R.H. 2005. What Price the Moral High Ground? Ethical Dilemmas in Competitive Environments. Princeton University Press, Princeton New Jersey.

Ghaffari, F., Kyriacou, O. \& Brennan, R. 2008. Exploring the Implementation of Ethics in U.K. Accounting Programs. Issues in Accounting Education, 23(2): 183-198.

Guffey, D. \& McCartney, M. 2008. The Perceived Importance of an Ethical Issue as a Determinant of Ethical Decision-making for Accounting Students in an Academic Setting. Accounting Education, 17(3): $327-348$.

Harman, G. 2000. The non-existence of character traits, Proceedings of the Aristotelian Society. 100: $223-226$.

Haswell, S. \& Jubb, P. 1995. Unethical tendencies. Charter 66(3): 102-103.

IRBA (Independent Regulatory Board for Auditors). 2014. [Online]. Available: http://www.firststep.me/ ultimate-careers/careers-uncut/1132-south-africa-maintains-first-position-for-the-strength-ofauditing-and-reporting-standards-for-four-years-in-a-row. [Last accessed 29 August 2014].

International Federation of Accountants (IFAC) 2014. Code of Professional Conduct, South African Institute of Chartered Accountants Members' Handbook, 2014 Edition, Volume 2A: LexisNexis, Pietermaritzburg.

Jackling, B., Cooper, B.J, Leung, P. \& Dellaportas, S. 2007 Professional Accounting Bodies' Perceptions of Ethical Issues, Causes of Ethical Failure and Ethics Education. Managerial Auditing Journal, 22(9): 928944.

Kohlberg, L. 1969. Stages and sequences: The cognitive development approach to socialization (pp. 485-546). In Goslin, D. (Ed.), Handbook of Socialization Theory and Research. Chicago, IL: Rand McNally.

Lampe, J. 1996. The Impact of Ethics in Accounting Curricula. Research on Accounting Ethics, 2: 187-220.

Langlois, L., \& Lapointe, C. 2010 Can ethics be learned? Results from a three-year action-research project. Journal of Educational Administration, 48(2): 147-163.

Loeb, S.E. 2007. Issues relating to teaching accounting ethics: an 18 year retrospective. Research on Professional Responsibility and Ethics in Accounting, 11: 1-30.

Low, M., Davey, H. \& Hooper, K. 2008. Accounting Scandals, ethical dilemmas and educational challenges. Critical perspectives on Accounting, 19(2): 222-254.

Mandela, N. 1995. Speech to Parliament (February 17, 1995), quoted in: Rossouw, G. 1997. Business Ethics in South Africa. Journal of Business Ethics, 16: 1539-1547.

Mitchem, C.E. 2009. Analysis of International Ethical Standards in Accounting. International Business and Economic Research Journal, 8(1): 41-49.

Morris, M.H., Marks, A.S., Allen, J.A., \& Peery N.S. 1996 Modeling Ethical Attitudes and Behaviors under Conditions of Environmental Turbulence: The Case of South Africa. Journal of Business Ethics, 15: 11191130.

Moore, R.S. \& Radloff, S.E 1996 Attitudes Towards Business Ethics Held by South African Students. Journal of Business Ethics, 15: 863-869.

Motlanthe, K. 2011. Address at the University of the Witwatersrand, Johannesburg (February 17, 2011): The Presidency Republic of South Africa. [Online] Available: http://www.thepresidency.gov.za/pebble. asp?relid=4682 [Last accessed on 26 May 2015].

Nejati, M., Ismail, S. \& Shafaei, A. 2011. Students' unethical behaviour: Insights from an African country. Global Business and Management Research: An International Journal, 3(3-4): 276-295. 
Nienaber, S.G. 2010. Factors that could influence the ethical behaviour of tax professionals. Meditari Accountancy Research, 18(1): 33-46.

Ogunyemi, K 2013. Ethics education and locus of control: Is Rotter's scale valid for Nigeria? African Journal of Business Ethics, 7(1): 1.

O'Leary, C. \& Cotter, D. 2000. The ethics of final year accountancy students: an international comparison. Managerial Auditing Journal, 15(3): 108-115.

O'Leary, C. 2009. An Empirical Analysis of the Positive Impact of Ethics Teaching on Accounting Students. Accounting education: an international journal, 18(4-5): 505-520.

Painter-Morland, M. \& Werhane, P. 2008. Cutting Edge Issues in Business Ethics Continental challenges to Tradition and practice: Springer, Chicago.

Piper, T.R., Gentile, M.C. \& Parks, S.D. 1993. Can Ethics Be taught? Perspectives, Challenges and Approaches at Harvard Business School. Boston Harvard Business School, United States of America.

Ponemon, L.A. 1993. Can Ethics be taught in accounting? Journal of Accounting Education, 11(2): 185-209.

Preble, J.F. and Reichel, A. 1988. Attitudes towards business ethics of future managers in the US and Israel. Journal of Business Ethics, (7): 941-949.

Rest, J. 1986. Moral Development: Advances in Research Theory. Praeger, New York.

Robinson, D.A., Davidsson, P., Van der Mescht, H. \& Court, P. 2007. How Entrepreneurs Deal with Ethical Challenges - An application of the Business ethics synergy star technique. Journal of Business Ethics, 71(4): 411-423.

Rossouw, D., du Plessis, C., Prinsloo, F. \& Prozesky, M. 2011. Ethics for Accountants and Auditors, 2nd edition. Oxford University Press, Cape Town.

Rossouw, G.J. 1997. Business Ethics in South Africa. Journal of Business ethics, 16(14): 1539-1547.

Salter, S., Guffey, D. \& McMillan, J. 2001. Truth, Consequences and Culture: A Comparative Examination of Cheating and Attitudes about cheating among US and UK Students. Journal of Business Ethics, 31: $37-50$.

Shaw, W.H. 2008. Business Ethics. Wadsworth Inc., Belmont California.

Shaub, M. 1994. An analysis of factors affecting the cognitive moral development of auditors and auditing students. Journal of Accounting Education: 1-24.

SAICA 2011a, July 29. CA (SA) Training Programme, November 2011, [Online]. Available: https://www.saica. co.za/Training/Training/CASATrainingProgramme/tabid/1657/language/enUS/Default.aspx [Accessed on 27 August 2014].

SAICA 2011b, November 7. The value of the CA (SA) Designation, SAICA Member Services Newsletter, newsletters@saica.ensight.co.za.

SAICA 2012, October 23. CA World, Member subscriptions 2013 Newsletter, newsletters@saica.ensight.co.za.

The SAICA (South African Institute of Chartered Accountants) Code of Professional Conduct. 2015. [Online]. Available: https://www.saica.co.za/Technicallnformation/Discipline/CodeofProfessionalConduct/ tabid/701/language/en-ZA/Default.aspx [Accessed on 29 May 2015].

The SAICA (South African Institute of Chartered Accountants) Competency Framework (2010). [Online]. Available: https://www.saica.co.za/trainees/training/theca2010trainingprogramme/tabid/1657/ language/en-US/default.aspx [Accessed on 27 August 2014].

Tang, T.L. \& Chen, Y. 2008. Intelligence vs. Wisdom: The love of Money, Machiavellianism, and Unethical Behaviour across college major and gender. Journal of Business Ethics, 82(1): 1-26.

Transparency International 2014. Corruption Perceptions Index. [Online]. Available: https://www. transparency.org/cpi2014/results [Accessed on 13 December 2014].

Verschoor, C.C. 2004. Accountancy students develop a unique code of ethics. Strategic Finance, 86(2): 15-16.

Vitell, S.J, Nwachukwu S.L. \& Barnes, J.H. 1993. The Effects of Culture on Ethical Decision-Making: an Application of Hofstede's Typology. Journal of Business Ethics, 12: 753-760.

World Economic Forum 2014. Global Competitiveness Report 2013-2014, February 2014. [Online]. Available: http://www.weforum.org/reports [Accessed on 2 June 2014]. 